\title{
Influence of procurement strategies on public projects implementation in Rwanda case of village road construction project in Kicukiro district.
}

\author{
Penelope Kayitesi ${ }^{1}$, Hakizimana Khan Jean De Dieu ${ }^{1}$ \\ ${ }^{1}$ School of business and economics, Mount Kenya University, Kicukiro P.O.Box 5826 MKU Plaza, Along Avenue de la Paix \\ Kigali, Rwanda \\ DOI: 10.29322/IJSRP.11.06.2021.p11412 \\ http://dx.doi.org/10.29322/IJSRP.11.06.2021.p11412
}

\begin{abstract}
The study was to investigated the influence of procurements strategies on public projects implementation in Rwanda especially village road construction projects in Kicukiro district, Rwanda. A descriptive research design was adopted using both qualitative and quantitative approaches. The target population was 367 . With a sample of the size $n=79$. The researcher used questionnaires and interviews. The researcher used Data analysis using statistical package for social sciences. Results revealed that the regression analysis R2 was 0.884 indicating that procurement strategies are important to enhance, promote village roads construction projects implementation and raise the transport service delivery in Kicukiro.
\end{abstract}

\section{INTRODUCTION}

$\mathrm{P}$ ublic procurement is necessary and very important to the governmental functioning because that is where the major expenses go through. It is concerned then with the reception of items, operations of service delivery and labor that consumes the government treasure (World Bank, 2010). As an example, fixed assets, rising of buildings and other infrastructure, keeping cleanliness, transportation of people and materials with expert payment. Throughout the world, debates are varied and many people are attentive to the public procurement, it brings to different restructuring activities. According to Roodhooft and Abbeele (2016), governmental agencies always buy things, spending a great budget. Mahmood (2010) said that the procurement at nations' level consumes $18.42 \%$ of the GDP at World Bank.

Both in the developed countries as well as in third world countries have developed reforms and regulations about buying. Still the biggest trouble is there is no identification of complete resolution. De Boer and Telgen (2017) said that lack of complete regulations affects both the poor countries and the developed ones. The transparency International Rwanda wrote a 2006 declaration that the process of buying goods took a half of the sum total of national budget. Typically, the calculations found procurement strategies have impact of thirteen per cent of GDP and forty per cent of public expense. In fact, without counting the wages to workers, even before debts are paid, the buying itself takes more than a half of the total expenses (MINECOFIN, 2011).
Kicukiro has implemented many public projects such as road construction projects, hygiene improvement projects, school construction projects. In this district once you make circulation in roads constructed, you face different areas where some roads are smaller than other areas in same district, roads destructed in different village of district, lack of water canalization, absence of small bridges to divert rainwater by roadsides, lack of hygiene around the roads compared with other areas of district. Here we can say roads of the whole village of Kigarama sector, Gatenga sector and some village of Kanombe, Niboye sector are poorly constructed compared with other roads of Kicukiro those issues impact the transport services.

The objectives of the paper are:

i. To assess procurement strategies used in public project implementation in Rwanda at Kicukiro District.

ii. To examine the impacts of implementation on construction projects in Kicukiro district, Rwanda

iii.To establish the relationship between procurement strategies and implementation of village roads construction projects in Kicukiro District, Rwanda

\section{LITERATURE REVIEW}

Companies implement purchasing strategies in order to make cost effective and it is necessary to put in place strategies that will ensure the project is a success and fits within the budgeted amount local or multinational companies use different strategies depending on purchasing power. There are many purchasing strategies like supplier optimization. Supplier chooses many suppliers to provide prices to select the best least prices.

Frame (2013) defines the salient features of a project as goal oriented that involves actions, which are joined one another under control and they are timely striving to the known end as the starting also is to be exact, as are all particular. Besides, Lock (2018) defines a project as a combination of works that are enrolled in planned way and that has a precisely illustrated beginning and ending purposed to attain sure results expected to meet required goals. The main features of a project include a clear scope and clear objectives (Kerzner, 2010).

The method of procurement influences project implementation. The Procurement strategies determines the 
choice of delivery method that determines the rate of project implementation. Characteristics of alternative procurement procedures are revised techniques of tender, procurement at time, demanding for suppliers, selection of prices that are cheaper. To choose the application approach it is necessary to redirect to price with competitors and search for a qualitative and least expensive. In emergency procurement, project implementation is faster than other procurement procedure (Gadde, 2019). That is the writing of a document explaining the reasons for selection of the contractor, precision of the needed expense compared to others and the market products to get as related to the rejected ones.

The implementation stage is endowed with strong control due to its high importance. Time lost in the earlier period of the enrollment is normally made up in the simple implementation duration. In that case, this state requires pressure to the employees, strong oversea and always inspiration (PMBOK 2018).

The research implores public Procurement for creative ideas in relation with problems anticipation and suggestion of strategies to win the difficulties. Three dimensions are shown as the principles: the consumer of the products to provide; features of the engagement; and the natural state of system whether in-group or individual. Moreover, illustrating the heading steps in creating new strategies emanating with factual claim the contribution of procurement at open public on transparency and increment of trust among all entities and individuals as well; and likely resolutions of probable disputes become agreed upon (Edquist \& Zabala, 2012).

The strategies of buying publicly are very beneficial to the daily life of citizens and it advances the good conduction of established orientations. It shows the concerned organs the difficult issues they are likely to meet. They show difficulties and reveal new advantages, as the technology is advancing on how to maximize gain (Moe \&Päivärinta, 2013).

On the procurement strategies affecting effective public projects implementation in Rwanda (Nzaramba,2014), found that to plan for procurement should be customized as it is very highly valuable and the research will raise all issues related with that failure of project to avoid the future project failures. Then if it is considered as prior the effectiveness results. Studies done on the concept of procurement strategies and project implementation both locally and internationally, but little was done on the influence of public procurement strategies on project implementation (Chandra, 2018).
Independent variable

\section{Dependent variable}

Public project implementation

- Current resource Allocation

- Deviation of money

- Planned Budget

- Cost Variance in the plan

- Periodical delivery of experimentation

- Quality of the project

Intervening variables

- Policy making

- The socio-cultural factors,

- Stakeholders involvement

\section{Figure 2.1 Conceptual framework}

\section{Source: Researcher (2020)}

Figure 2.1 shows how procurement strategies (independent variables) influence public projects implementation (dependent variable) hence affecting the community (intervening variables). In this research, we found how procurement procedures influence the implementation of village roads construction projects in Kicukiro District, the influence and implementation of the good policies made, interventions of social cultural factors and high appreciation of the stakeholder involvement to enhance the procurement strategies elaborated by Kicukiro district staff in the areas of construction implementation.

\section{RESEARCH DESIGN AND METHODOLOGY}

The researcher adopted the descriptive survey design; this is an appropriate choice basing on progressive inquiry concerning the role of tendering strategies on project implementation of village roads construction projects in Kicukiro district. Yamen formula (1970) involves in calculating the sample size from target population: when the population is 367 , the possible sample is 79 respondents. 
$n=\frac{N}{1+N(e) 2}$

Source: Yamane, 1970

$\mathbf{N}$ : stands for the target population

e: precision level equals to $(10 \%)$

n: Sample size

$n=\frac{367}{1+367(0.1)^{2}}=\frac{367}{1+367(0.01)} n=78.58 \simeq 79$

The study choose to use sampling randomly to select the project managers; Simple Stratified sampling was used to select procurement officers and researcher used purposive sampling technique to select project beneficiaries. This technique of sampling used was basing on the experience, qualities, and awareness in all respondents to provide virtue information. According to Bernard(2012) stated the purposive sampling or judgment sampling technique is the deliberate choices of the researcher due to the qualities the respondents possess and the simple random sampling were used to select the respondents from sample size.
Method for getting data is an organized approach to arrive at needed news as reflecting purposes of the research (Burns \& Grove, 2013). The researcher used the combined method that consisted of descriptive survey and interview. The descriptive survey used by the researcher because of limited time of research project to deal with a large number of respondents from the Kicukiro district the respondents under investigation geographically dispersed in the area under investigation.

\section{DATA ANALYSIS AND RESULTS}

The total number of the respondents was 79 and they were made of 2 Project managers, 4 Committee members, 69 Project beneficiaries, 3 Procurement Officer and 1 Chairperson. Questionnaires were distributed to 69 Project beneficiaries, 4 committee members, 3 procurement officers and the interview was reserved for the 2 project managers and 1 and project chairman. The questionnaire return rates were $100 \%$ of those who returned their questionnaires. The return rate is computed in Table 4.1

Table 4. 1 Questionnaire return rate by the category of respondents

\begin{tabular}{llll}
\hline & statement & Frequency & Valid Percent \\
\hline Valid & Procurement officer & 3 & 3.9 \\
& Project beneficiaries & 69 & 90.8 \\
& Committee member & 4 & 5.3 \\
& Total & $\mathbf{7 6}$ & $\mathbf{1 0 0 . 0}$ \\
\hline
\end{tabular}

Source: Research (2020)

The findings from the study indicated that $100 \%$ of all participants returned their questionnaires .The researcher managed the interview to all respondents interviewed in the selected construction projects and they all gave relevant information required by the researcher. The main purpose of this study was to assess the impact of procurement strategies on public project implementation a case of village roads construction projects in
Kicukiro district. To achieve this objective, the researcher used three specific objective that were: To assess procurements strategies used in public project implementation in Rwanda, to indicate the impact of procurement strategies on implementation of construction projects in Kicukiro district, Rwanda, and to show the relationship between procurement strategies and implementation of village roads construction projects in Kicukiro District, Rwanda.

Table 4. 2 Procurement strategies used in public project implementation

\begin{tabular}{|c|c|c|c|c|c|c|c|c|c|c|c|c|}
\hline Facilities & SD & $\%$ & D & $\%$ & $\mathbf{N}$ & $\%$ & $\mathbf{A}$ & $\%$ & SA & $\%$ & Mean & Std.dev \\
\hline Identification of needs & 6 & 7.9 & 5 & 6.6 & 3 & 3.9 & 25 & 32.9 & 37 & 48.7 & 4.0789 & 1.23032 \\
\hline $\begin{array}{l}\text { Enquiry ,supplier relationship } \\
\text { M\&E }\end{array}$ & 2 & 2.6 & 3 & 3.9 & 0 & 0 & 41 & 53.9 & 30 & 39.5 & 4.2368 & .86207 \\
\hline $\begin{array}{l}\text { Determine the specification and } \\
\text { negotiation }\end{array}$ & 9 & 11.8 & 5 & 6.6 & 12 & 15.8 & 19 & 25.0 & 30 & 40.8 & 3.7632 & 1.36498 \\
\hline $\begin{array}{l}\text { Ordering and Progressing } \\
\text { Sourcing and Delivery of Goods }\end{array}$ & 7 & 9.2 & 12 & 15.8 & 3 & 3.9 & 16 & 21.1 & 38 & 50.0 & 3.8684 & 1.41744 \\
\hline & 14 & 18.4 & 6 & 7.9 & 1 & 1.3 & 21 & 27.6 & 34 & 44.7 & 3.7237 & 1.54574 \\
\hline $\begin{array}{l}\text { Procurement planning for cost } \\
\text { reduction } \\
\text { Payment and Receiving }\end{array}$ & 6 & 7.9 & 1 & 1.3 & 4 & 5.3 & 9 & 11.8 & 56 & 73.7 & 4.4211 & 1.18054 \\
\hline materials & 4 & 5.3 & 9 & 11.8 & 3 & 3.9 & 30 & 39.5 & 30 & 39.5 & 3.9605 & 1.18255 \\
\hline
\end{tabular}




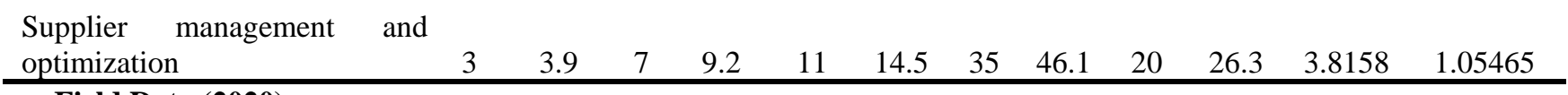

Source: Field Data (2020)

The findings indicated in table 4.2 and the results revealed that the respondents showed their perception and how they understand, the procurement strategies used in public projects implementation and the procurements strategies stated in the table 4.4 which indicate the perceptions from respondents on each strategy. The first strategy established was the identification of the needs of the projects and its objective, the majority of respondents $81.6 \%$ indicated that they used the identification of needs strategy in the implementation of public projects like roads construction. The $14.5 \%$ of participants disagree with the use of this strategy in the village roads construction projects. While $3.9 \%$ of participants refused to show their side on the use of needs identification strategy in the village roads construction projects. The second strategy raised was enquiry, supplier relationship, and Monitoring and Evaluation strategy. The results showed that the majority 93.4\% of respondents accepted the use of the enquiry, supplier relationship, monitoring and evaluation strategy in the village roads construction projects implementation and the $6.5 \%$ of participants disagreed with the statement. This strategy used in the public project implementation with the mean of 4.2368 and its standard deviation of 0.86207 means the respondents agreed that there is a big role of the Enquiry, supplier relationship, and Monitoring and evaluation strategy in the village roads construction Implementation.

The firth strategy assessed the use of sourcing and delivery of goods strategy. The respondents showed their perception and they indicated that they use the Sourcing and Delivery of Goods strategy with the $72.3 \%$ of respondents accepted that they use this strategy to achieve projects objectives. The $26.3 \%$ disagreed with the statement that they do not use this strategy in the village roads construction projects implementation and the $1.3 \%$ refused to say anything meaning that they do not know if the strategy was used in the project activities with mean of 3.7237 and its standard deviation of 1.54574 .

The sixth strategy addressed was the Procurement planning for cost reduction in the construction projects where the majority
$85.5 \%$ of respondents admired the strategy in the village roads construction projects implementation and the $9.2 \%$ of participants disagreed with the use of this strategy. The $5.3 \%$ of respondents refused to show their side about the use of the Procurement planning for cost reduction in the construction projects with the mean of 4.4211 and its standard deviation of the 1.18054.

In the project implementation activities, the selling, buying and good materials selection is very important strategy to meet the projects implementation therefore the seventh strategy highlighted was the Payment and receiving materials. The majority $79.0 \%$ of respondents agreed that they used this strategy to pay all needed materials , pay all manpower, pay engineers salaries and use it in the selection ,controlling and in the receiving of good materials needed for projects activities. The $17.1 \%$ of respondents indicated that they do not use this strategy and the $3.9 \%$ were neutral to the statement with the mean of 3.9605 and its standard deviation of 1.18255. The last strategy indicated in this section was the Supplier management and optimization for procurement procedure strategy where every project should have supplying management strategy therefore the $72.4 \%$ of participants indicated that they used this strategy. The $13.1 \%$ of participants indicated that they do not need this strategy to achieve projects mission while the $14.5 \%$ of respondents refused to show their aside about the use of the Supplier management and optimization for procurement procedure strategy with the mean of 3.8158 and its standard deviation of 1.05465 . The method of procurement influences project implementation. Interviews with participants on the village roads construction projects implemented in Kicukiro and they said, "we respected different procurement strategies in the village roads construction projects implementation. The most usable procurement strategies are identification of Needs, Determine the specification, Enquiry and Evaluation, Negotiating, sourcing, Ordering and Progressing, Delivery of Goods, Payment and Receiving, those strategies facilitate the projects team to complete the projects activities timely". 
Table 4.3 Impact of procurements strategies on projects implementation.

\begin{tabular}{|c|c|c|c|c|c|c|c|c|}
\hline \multirow[t]{2}{*}{ Statement } & \multicolumn{2}{|c|}{$\begin{array}{l}\text { Disagree } \\
\text { d }\end{array}$} & \multicolumn{2}{|c|}{ Neutral } & \multicolumn{2}{|c|}{ Agreed } & \multirow{2}{*}{$\begin{array}{l}\text { Mean } \\
\text { Statistic }\end{array}$} & \multirow{2}{*}{$\begin{array}{l}\text { Std. Devi } \\
\text { statistic }\end{array}$} \\
\hline & $\mathbf{N}$ & $\%$ & $\mathbf{N}$ & $\%$ & $\mathbf{N}$ & $\%$ & & \\
\hline $\begin{array}{l}\text { Enquiry ,supplier relationship, Monitoring \&Evaluation } \\
\text { ensure the implementation of village roads construction } \\
\text { projects implementation }\end{array}$ & 39 & 51.3 & 8 & 10.5 & 29 & 38.2 & 2.8158 & 1.43954 \\
\hline $\begin{array}{l}\text { Procurement planning for cost reduction ensures } \\
\text { implementation of projects accomplishment }\end{array}$ & 4 & 5.3 & 0 & 0 & 72 & 94.7 & 4.4737 & .90146 \\
\hline $\begin{array}{l}\text { The supply chain function are coordinated by the } \\
\text { procurement unit to ensure the project implementation } \\
\text { progress }\end{array}$ & $2 ?$ & 30.3 & 0 & 0 & 53 & 69.7 & 3.7763 & 1.34262 \\
\hline $\begin{array}{l}\text { Supplier management and optimization for procurement } \\
\text { procedure influence positively the public project } \\
\text { implementation }\end{array}$ & 11 & 14.5 & 7 & 9.2 & 58 & 76.3 & 3.6579 & 1.11418 \\
\hline $\begin{array}{l}\text { Procurement negotiation and Determination the } \\
\text { specification influence construction projects implementation }\end{array}$ & 13 & 17.1 & 2 & 2.6 & 61 & 80.2 & 4.1579 & 1.33719 \\
\hline $\begin{array}{l}\text { Payment, receiving materials, sourcing and delivery of } \\
\text { Goods enhance the projects implementation }\end{array}$ & 11 & 14.5 & 4 & 5.3 & 61 & 80.2 & 3.6579 & 1.11418 \\
\hline
\end{tabular}

The second statement highlighted was how respondents were concerned about Procurement planning for cost reduction ensuring implementation of projects accomplishment, where the $94.7 \%$ of respondents indicated that procurement planning for cost reduction has affected the projects implantation activities. $5.3 \%$ of respondents disagreed on the statement means they do not know how procurement planning impacted the village roads construction projects implementation in Kicukiro district and this statement was on the mean of 4.4737 and its standard

Deviation of .90146 therefore procurement planning for cost reeducation affected significantly the implementation of village roads construction projects. The third point was how supply chain function is coordinated to influence the implementation of village roads construction projects activities. $69.7 \%$ of respondents agreed with the statement by saying that the procurement unit to ensure the project implementation progress coordinates the supply chain function. $30.3 \%$ were not sure if procurement unit manage all supply chain activity to enhance the progress of projects activities with the mean of 3.7763 and its standard deviation of 1.34262 , this indicates high mean to prove that the supply chain function was managed by the procurement unit in Kicukiro district. Another point was on how Supplier management and optimization for procurement procedure influence positively the public project implementation where the majority $76.3 \%$ of participants confirmed that this strategy affected the projects activities. While the $14.5 \%$ disagreed with this statement and $9.2 \%$ were neutral to the statement, means that they refused to show their side about how Supplier management and optimization for procurement procedure influence positively the public project implementation. It has the mean of 3.6579, which is high to accept the influence of Supplier management and optimization for procurement procedure strategy in the implementation of village roads construction projects activities.
Payment, receiving materials, sourcing and delivery of Goods and the $14.5 \%$ of respondents disagreed on this statement while the 5.3\% refused to show their views about the importance of the Payment, receiving materials, sourcing and delivery of Goods to promote and enhance construction projects activities implementation. This statement was on the mean of 3.6579 and its standard deviation of 1.11418 which is a very high mean to explain that Payment, receiving materials, sourcing and delivery of Goods strategy is highly appreciated in the village roads construction projects in Kicukiro district.

The interviews with the respondents about the influence of procurement strategies on village roads construction projects. The first question was: In what other ways does procurementplanning process affect the implementation of village roads construction projects in Kicukiro District? They answered that if the project team plans clearly all measures, strategies and procedure before the projects works start, the implementation activity be influenced and all tasked group manage their side to achieve the projects objective"

Table 4.4 The relationship between procurement strategies with public projects implementation. The researcher wanted to assess the link of procurement strategies and public projects therefore the results shown in the table 4.4 


\begin{tabular}{|c|c|c|}
\hline Statement & Mean & Std. Deviation \\
\hline $\begin{array}{l}\text { The choice of procurement procedure influence village roads } 76 \\
\text { construction projects implementation }\end{array}$ & 3.8947 & 1.28145 \\
\hline $\begin{array}{l}\text { Accountability of project resources ensures success of } 76 \\
\text { implementation }\end{array}$ & 3.6316 & 1.28418 \\
\hline $\begin{array}{l}\text { The Project duration and planning determines the success of village } \\
\text { roads construction project implementation }\end{array}$ & 3.5263 & 1.35128 \\
\hline $\begin{array}{l}\text { The procurement strategies relate village roads construction projects } 76 \\
\text { implementation }\end{array}$ & 4.3816 & .99287 \\
\hline
\end{tabular}

\section{Source: Researcher (2020)}

The results revealed in table 4.4 indicated that the majority of respondents agreed that the choice of procurement procedure influence village roads construction projects implementation with the mean of 3.8947 which is a very high mean. The respondents showed that they agree with good accountability of project resources, which ensures success of implementation of village roads construction projects in Rwanda especially those of Kicukiro district with mean of 3.6316 , which is high to appreciate this strategy.

The third point of this objective was to see if the Project duration and planning determine the success of village roads construction project implementation. The respondents showed their side of agreement and they indicated that they agreed with the mean of 3.5263, this means that duration and projects planning are very needed strategies to be undertaken in the projects implementation. Another idea was generally how all procurements strategies affect projects implementation, participants strongly agreed that any project should be implemented with the planned and clear procurements strategies and measures in this statement were on the mean of 4.3816 indicating that majority of respondents appreciate the role played by procurements strategies in the implementation of village roads constructions projects. The results indicated in the 4.4 revealed that procurement strategies have a very big relationship with the implementation of village roads construction projects in Kicukiro district ,Rwanda therefore researcher intended to assess the correlation of the two variables and the results were summarized in the table 4.5

The findings shown in the table 4.5 revealed that procurement strategies were correlative with the success of implementing the village roads construction projects in Kicukiro district, this was indicated by the Pearson Correlation coefficient (r) of 0.940 which was obtained with the P-value of 000 of a 2tailed to show that the variables are strongly positive and statistically significant. This means that effective procurement strategies affect significantly the implementation of village roads construction projects in Kicukiro district.

Table 4. 5 Correlation of variable

\begin{tabular}{llll}
\hline Statement & \multicolumn{2}{c}{ implementation of village roads } \\
& construction projects & Procurement strategies \\
\hline Implementation of village Pearson & 1 & $.940^{* *}$ \\
road construction projects & Correlation & & .000 \\
& Sig. (2-tailed) & & 76 \\
& $\mathrm{~N}$ & 76 & 1 \\
Procurement strategies & Pearson & $.940^{* *}$ & \\
& Correlation & .000 & 76 \\
\hline
\end{tabular}

**. Correlation is significant at the 0.01 level (2-tailed).

Source: Researcher (2020)

\begin{tabular}{llllcl}
\hline Model & R & $\begin{array}{l}\text { R } \\
\text { Square }\end{array}$ & $\begin{array}{l}\text { Adjusted } \\
\text { Square }\end{array}$ & $\begin{array}{c}\text { R Std. Error of } \\
\text { the Estimate }\end{array}$ & $\begin{array}{c}\text { Durbin- } \\
\text { Watson }\end{array}$ \\
\hline 1 & $.940^{\mathrm{a}}$ & .884 & .883 & .44001 & .264 \\
\hline
\end{tabular}

a. Predictors: (Constant), procurement strategies

b. Dependent Variable: implementation of village road construction projects 
The findings of the study sees to conjure with many reviewed studies such as hall (2005) and Mussa (2015) which all indicated that procurement practices played an important role on implementation of village roads construction projects especially in public institutions like Kicukiro district.
Findings in this study showed a positive influence of procurement strategies on construction projects implementation in Kicukiro district to enhance the transport service delivery as indicated by the regression analysis model in the table 4.6.

Table 4.6 Regression analysis model of the two variables

\begin{tabular}{lllllll}
\hline Model & & Sum of Squares & df & Mean Square & F & Sig. \\
\hline 1 & Regression & 109.357 & 1 & 109.357 & 564.841 & $.000^{\mathrm{a}}$ \\
& Residual & 14.327 & 74 & .194 & & \\
& Total & 123.684 & 75 & & & \\
\hline
\end{tabular}

a. Predictors: (Constant), procurement strategies

b. Dependent Variable: implementation of village road construction projects

The results revealed that the procurement strategies must be coherent with implementation of construction Projects especially the village roads construction projects as shown with the regression analysis $\mathrm{R}$ Square of 0.884 . This finally shows that procurement Strategies are needed to enhance and promote village roads construction projects implementation and raise transport service delivery in Kicukiro district. The method of procurement influences projects implementation. This was supported that procurement strategies determines the choice of delivery method, which determines the rate of project implementation. Alternative procurement procedures are characterized by: revised techniques of tender, procurement at time, demanding for suppliers, selection of prices that are cheaper and to choose the application approach it is necessary to redirect to price with competitors and search for a qualitative and least expensive. In emergency procurement, project implementation is faster than other procurement procedure (Lysons \& Farrington, 2010).

\section{DISCUSSION}

This part details the enquiry discoveries on each objective and the inhabitant situation of participants to the research has good impact on results. It was noticed that most people in investigation worked with Kicukiro district especially projects beneficiaries for a long period, hence a good experience in the area, coupled with the relevant education level needed to enhance the reliability of the information that they provided.

The study revealed a strong positive correlation between village roads construction project implementation and Procurement strategies largely. Proper sequencing of procurement process, scheduling of events and activities definition results to a successful procurement process and successful projects implementation. Further, the study revealed that project implementation structure is affected by the strategic choices, as norm based organization activities is a strong foundation on the projects and the shape of work is in need of combining varied people's efforts.

There is a strong positive relationship between Project execution and Contract supervision and prescription. Further, monitoring and evaluation exists in fostering construction project implementation largely.
Procurement unit ensures implementation of project in Kicikiro district and coordinates supply chain function, monitoring and evaluation system ensure that the implementation of village roads construction projects and monitoring triggers off an effort to search for solutions to the identified threats to the project success.

The study revealed that Kicukiro District uses pricing and terms to determine the procurement negotiating process and environmental fluctuations was found to influence procurement negotiation toward implementation parties who negotiate were found to agree and builds trust to create a commitment structure that is implemented on stages. There was a strong positive correlation between village roads construction Project implementation and procurement strategies. Procurement negotiation influences to construction projects implementation in Kicukiro district.

The study revealed that there is a strong positive correlation between project implementation and Procurement strategies were correlative with the success of implementing the village roads construction projects in Kicukiro district. Pearson Correlation coefficient (r) of 0.940 that obtained with the P-value of 000 of a 2-tailed indicated that variables are strongly positive and statistically significant. This means that effective procurement strategies affect significantly the implementation of village roads constructions projects in Kicukiro district. This finding concurs to that of Frese (2013), who emphasizes that planning requires an interactive process that requires agile re-thinking. Finally, the research established that the procurement method is dictated by the estimated cost. This finding is in line with (Gadde, 2009) that choice of procurement procedure influences project implementation. The results revealed that the procurements strategies must be coherent with implementation of construction projects especially the village roads construction projects as shown with the regression analysis $\mathrm{R}$ square of 0.884 indicating that procurement strategies are important to enhance, promote the village roads construction projects implementation and raise the transport service delivery in Kicukiro district. The method of procurement influences project implementation where by procurement strategies determine the choice of delivery method, which determines the rate of project implementation. Alternative procurement procedures reflected by revised techniques of tender, 
procurement at time, demanding for suppliers, selection of prices, which are cheaper, and to choose the application approach it is necessary to compare prices with competitors and search for a qualitative and least expensive. In emergency procurement, project implementation is faster than other procurement procedure (Lysons \& Farrington, 2010)

\section{CONCLUSION}

The research presented a complete understanding of procurement strategies' addition on construction of transport service infrastructure in Kicukiro district. The study concluded that there is a strong positive correlation between Project implementation and Procurement strategies within construction projects of transport service infrastructure in Kicukiro. Proper sequencing of procurement process, scheduling of events and activities definition results to a successful procurement process. Strategic choices affect Project planning structure, a good plan is the beginning of smoothness in projects and its conditions are collaboration of different visionary characters.

Further, it concluded that monitoring and evaluation influence village roads construction projects implementation to a great extent and a strong positive correlation between Project implementation and Monitoring and Evaluation exist. Procurement unit ensures implementation of project in Kicukiro and coordinates supply chain function. Monitoring and evaluation system ensures that the projects objectives are accomplished in Kicukiro and Monitoring triggers off an effort to search for solutions to the identified threats to the project's success.

Finally, the study concluded that Procurement strategies influence village roads construction projects implementation largely and a strong positive correlation exists between Project implementation and Procurement strategies. The choice of procurement strategies is dictated by the estimated cost in Kicukiro district. The institution also uses pricing and terms to determine the procurement negotiating process and environmental fluctuations influence procurement strategies. A strong positive correlation between village roads construction Project implementation and Choice of Procurement strategies was established.

\section{FUTURE RESEARCH}

The study was conducted at Kicukiro district in transport Sector.

Therefore, it is suggested that a similar study be done in other boards in other field of the country.

The study suggested that further research be done on the effectiveness of public procurement strategies within public organization.

The study also suggested that further study be done on the strategies adopted to ensure effectiveness procurement services to give uniform and reliable result.

We suggested that further research on the role of the government and development partners in delivering construction projects in Rwanda be done.

We also suggested that further research be done on understanding of the impact foreigners have on local community during implementation of construction projects across the diverse communities in Rwanda.

\section{ACKNOWLEDGMENTS}

My faithful gratitude goes to Mount Kenya University for continuous efforts to transform me. I really appreciated the support and advice of lecturers in Mount Kenya University Rwanda, School of business.

\section{REFERENCES}

[1] Agaba, E. A. (2017). "Public procurement reform in developing countries. Advancing public procurement strategies

[2] Alaniazar, P. (2010). Balancing accountability and efficiency in a more competitive public sector environment. Australian Journal of Public Administration

[3] Behnam \&Bahreman. ( 2010). Investigating Benefits and Limitations of applying e-procurement in B2B Automakers companies in Iran, Lulea University of Technology, Master Thesis.

[4] Benston, G.J. \& Smith, Jr., C.W. (2016). A transaction cost approach to the theory of financial intermediation, Journal of Finance.

[5] Brown, B., \& Hyer, N. (2010). Managing Projects:A Team-Based Approach, International Edition, Singapore, Mc Graw-Hill.

[6] Cchristiam M. \& Alemante, E. G.( 2012). 'Assessment of Effectiveness of Public Procurement Process: the case study of Ministry of Finance and Economic Affairs In Tanzania', Master's Thesis, Sweeden, Karlstad Business School

[7] Cooper, D.R. \& Schindler, and P.S. (2016). Business Research Methods (8th $e d n)$. New York: McGrawHill.

[8] Creswell, J. W. (2013). Research Design: Qualitative, Quantitative, and Mixed Methods Approaches. Thousand Oaks: Sage Publications, Inc.

[9] Denscombe, M. (2018). Communities of Strategies: A Research paradigm for the Mixed Methods Approach. Journal of Mixed Methods Research.

[10] Edquist, R., \& zabala, K. (2012). Sustainable procurement in the Canadian construction industry: challenges and benefits. Canadian Journal of Civil Engineering.

[11] Erikson D. K. \& Nelsson E. (2018). Role of procurement practices on the performance of corporate organizations in kenya: a case study of Kenya National Police Service. International Journal of Academic Research in Business and Social Science.

[12] Farmer, D, \& Weele, V., (2011). Handbook of Purchasing Management. 2nd ed. Hampshire: Gower.

[13] Gadde, M.E. (2019). A conceptual model of the influences on sustainable public procurement. Journal of supply chain Management.

[14] Gebauer \& Sergev, ( 2011). Changing shapes of supply chains: how the internet could lead to a more integrated procurement function, University of California, Berkeley.

[15] Gray, B., \& Larson, N. (2013). Managing Projects: A Team-Based Approach, International Edition, Singapore, Graw-Hill

\section{AUTHORS}

First Author - Penelope Kayitesi, School of business and economics, Mount Kenya University, Kicukiro P.O.Box 5826 MKU Plaza, Along Avenue de la Paix, Kigali, Rwanda Second Author - Hakizimana Khan Jean de Dieu, School of business and economics, Mount Kenya University, Kicukiro P.O.Box 5826 MKU Plaza, Along Avenue de la Paix, Kigali, Rwanda 
International Journal of Scientific and Research Publications, Volume 11, Issue 6, June 2021

This publication is licensed under Creative Commons Attribution CC BY. 